\title{
Determination of desorption isotherms, latent heat and isosteric heat of pequi diaspore
}

\author{
Kelly A. de Sousa ${ }^{1}$, Osvaldo Resende ${ }^{2} \&$ Bruno de S. Carvalho ${ }^{3}$ \\ ${ }^{1}$ Instituto Federal Goiano/Laboratório de Pós-Colheita de Produtos Vegetais. Rio Verde, GO. E-mail: kellyapsousa@yahoo.com.br(Corresponding author) \\ ${ }^{2}$ Instituto Federal Goiano/Diretoria de Pesquisa e Pós-Graduação. Rio Verde, GO. E-mail: osvresende@yahoo.com.br \\ ${ }^{3}$ Instituto Federal Goiano. Rio Verde, GO. E-mail: bruno-sousa_18@hotmail.com
}

\section{Key words:}

hygroscopic equilibrium water activity

thermodynamic properties

\begin{abstract}
A B S T R A C T
The objective was to determine water sorption isotherms of diaspores of pequi fruits in order to obtain information on the amount of water that this product desorbs at the temperatures of $10,20,30$ and $40^{\circ} \mathrm{C}$ and water activities from 0.20 to 0.89 , adjusting different mathematical models to experimental data, and to determine its latent heat and isosteric heat. The equilibrium moisture content was obtained through the indirect static method, using the device Hygropalm Model Aw 1. The Modified Henderson model was the one that best fitted the data and was selected to predict the equilibrium moisture content of pequi diaspore. It was observed that the higher the temperature for the same equilibrium moisture content (\% d.b.), the higher the water activity values. As temperature values increased, there was a reduction in the vaporization latent heat of the product. Isosteric heat values of diaspores of pequi fruits in the moisture content range of 4.02 to 16.63 (\% d.b.) varied from $2,776.49$ to $2,558.39 \mathrm{~kJ} \mathrm{~kg}^{-1}$.
\end{abstract}

\section{Palavras-chave:}

equilíbrio higroscópico

atividade de água

propriedades termodinâmicas

\section{Determinação das isotermas de dessorção, calor latente e calor isostérico de diásporos de pequi}

\section{R E S U M O}

Objetivou-se, com este trabalho, determinar as isotermas de dessorção de água de diásporos de pequi a fim de obter informações da quantidade de água que este produto dessorve nas temperaturas de $10,20,30,40^{\circ} \mathrm{C}$ e atividades de água entre 0,20 e 0,89 , ajustar diferentes modelos matemáticos aos dados experimentais e determinar o calor latente e o calor isostérico. Para obtenção do equilíbrio higroscópico foi utilizado o método estático indireto com uso do equipamento Hygropalm Model Aw 1. O modelo Henderson Modificado foi o que melhor se ajustou aos dados sendo selecionado para predição do equilíbrio higroscópico dos diásporos de pequi. Verificou-se que quanto maior a temperatura para um mesmo teor de água de equilíbrio (\% b.s.) maiores são os valores de atividade de água. Com o aumento da temperatura ocorre redução da magnitude do calor latente de vaporização do produto. Os valores de calor isostérico para os diásporos de pequi na faixa de teor de água de 4,02 a 16,63 (\% b.s.) variaram de $2.776,49$ a $2.558,39 \mathrm{~kJ} \mathrm{~kg}^{-1}$. 


\section{INTRODUCTION}

In general, fruits from the Cerrado, such as pequi (Caryocar Brasiliense, CAMB.), are little studied and there is lack of information on the best form of processing and packaging, as the best conditions to promote the safe storage of the product. In the indigenous language, the word 'pequi' means 'prickly shell' (Souza \& Salviano, 2002) and the species has been studied because of its economic importance due to culinary use of its fruits, as sources of vitamins $\mathrm{E}$ and $\mathrm{B}$, and in the extraction of oil from the seeds for the production of cosmetics (Almeida \& Silva, 1994; Silva et al., 2001; Vera et al., 2005). Due to these characteristics, for both human consumption and industry, the fruit has been studied as a great potential to reach international markets (Pereira et al., 2014).

With the search for knowledge and techniques of conservation for the species from the Brazilian Cerrado, germplasm banks become an important alternative due to the preservation and propagation of species in extinction (Silva et al., 2001). Thus, studies on water removal in response to the drying of the product become an effective method in the control of microbial development and metabolism during the storage period (Osório et al., 2007; Panadés et al., 2008).

Water activity studies can be developed using sorption isotherms. The isotherm is a curve that describes, at a specific moisture content, the equilibrium relationship of an amount of water sorbed by the components of the biological material and the vapor pressure or relative humidity, at certain temperature. Many authors studied the sorption isotherms of various products, such as crambe fruits (Costa et al., 2015a), Buchenavia capitata seeds (Costa et al., 2015b), lyophilized yellow mombin pulp (Oliveira et al., 2014), guava in powder (Santos et al., 2014), 'caju-de-árvore do cerrado' (Anacardium othonianum) (Caetano et al., 2012).

In this context, this study aimed to determine water desorption isotherms of pequi diaspores, in order to obtain information on the amount of water that this product desorbs at the temperatures of $10,20,30$ and $40^{\circ} \mathrm{C}$ and water activities from 0.20 to 0.89 , adjust different mathematical models to the experimental data and determine its latent heat and isosteric heat.

\section{Material ANd Methods}

The experiment was conducted at the Laboratory of Postharvest of Vegetal Products, at the Federal Institute of Goiás Campus of Rio Verde, and ripe fruits were harvested and sent to the experiment of hygroscopicity. Pequi diaspores with moisture content 63.67 (\% d.b.) were subjected to drying in a forced-air oven at $75^{\circ} \mathrm{C}$ until reaching moisture contents of $16.6,13.1,8.7$ and 6.4 (\% d.b.), determined in an oven at $105 \pm 1{ }^{\circ} \mathrm{C}$, during 24 $\mathrm{h}$, in two replicates (Brasil, 2009). Desorption isotherms were determined through the indirect static method, in which water activity $\left(a_{w}\right)$ was determined using the device Hygropalm Model Aw 1. A sample of each moisture content with $23.0 \pm 2.0 \mathrm{~g}$ was placed in the container of the device, in three replicates, and then placed in a B.O.D. chamber, regulated at 10, 20, 30 and 40 ${ }^{\circ} \mathrm{C}$. Readings were performed after stabilization of temperature and water activity. The experimental data of water activity were adjusted to mathematical models frequently used for the representation of hygroscopicity of vegetal products, as shown in the Eq. (1) to (12).

- Modified BET

$$
X E=\frac{\left(a \cdot b \cdot a_{w}\right)}{\left\{1-\left(c \cdot a_{w}\right) \cdot\left[1+(b-c) \cdot a_{w}\right]\right\}}
$$

- BET

$$
\mathrm{Xe}=\left\{1 /\left[\left(1-\mathrm{a}_{\mathrm{w}}\right) \cdot(1 / \mathrm{a} \cdot \mathrm{b}+((\mathrm{a}-1) / \mathrm{a} \cdot \mathrm{b}))\right]\right\}
$$

- ChungPfost

$$
\mathrm{Xe}=\mathrm{a}-\mathrm{b} \cdot \ln \left[-(\mathrm{T}+\mathrm{c}) \cdot \ln \left(\mathrm{a}_{\mathrm{w}}\right)\right]
$$

- Copace

$$
\mathrm{Xe}=\exp \left[\mathrm{a}-(\mathrm{b} \cdot \mathrm{T})+\left(\mathrm{c} \cdot \mathrm{a}_{\mathrm{w}}\right)\right]
$$

- Modified Halsey

$$
\mathrm{Xe}=\left[\frac{\exp (\mathrm{a}-\mathrm{b} \cdot \mathrm{T})}{-\ln \left(\mathrm{a}_{\mathrm{w}}\right)}\right]^{1 / \mathrm{c}}
$$

- Henderson

$$
X e=\left\{\frac{\ln \left(1-a_{w}\right)}{(-a \cdot T+237.16)}\right\}^{1 / c}
$$

- Modified Henderson

$$
X e=\left\{\frac{\ln \left(1-a_{w}\right)}{[-a \cdot(T+b)]}\right\}^{1 / c}
$$

- Modified Oswin

$$
\mathrm{Xe}=\frac{(\mathrm{a}+\mathrm{b} \cdot \mathrm{T})}{\left[1-\mathrm{a}_{\mathrm{w}} / \mathrm{a}_{\mathrm{w}}\right]^{1 / \mathrm{c}}}
$$

- Peleg

$$
\mathrm{Xe}=\left[\left(\mathrm{a} \cdot \mathrm{a}_{\mathrm{w}}^{\mathrm{b}}\right)+\left(\mathrm{c} \cdot \mathrm{a}_{\mathrm{w}}^{\mathrm{d}}\right)\right]
$$

- Kuhn

$$
\mathrm{Xe}=\left[\frac{\mathrm{a}}{\ln \left(\mathrm{a}_{\mathrm{w}}\right)}\right]+\mathrm{b}
$$

- Sigma Copace

$$
\mathrm{Xe}=\exp \left\{\mathrm{a}-(\mathrm{b} \cdot \mathrm{T})+\left[\mathrm{c} \cdot \exp \left(\mathrm{a}_{\mathrm{w}}\right)\right]\right\}
$$


- Smith

$$
\mathrm{Xe}=\mathrm{a}-(\mathrm{b} \cdot \mathrm{T})-\mathrm{c} \cdot \ln \left(1-\mathrm{a}_{\mathrm{w}}\right)
$$

where:

$\mathrm{Xe} \quad$ - equilibrium moisture content, \% d.b.;

$\mathrm{a}_{\mathrm{w}} \quad$ - equilibrium water activity, \% d.b.;

$\mathrm{T}$ - temperature, ${ }^{\circ} \mathrm{C}$; and,

a, b, c and d - coefficients that depend on the product.

The degree of fit of each model was evaluated based on a 0.05 significance of the coefficient of regression by t-test, the magnitude of the coefficient of determination $\left(\mathrm{R}^{2}\right)$, the values of relative mean error $(\mathrm{P})$, estimated mean error $(\mathrm{SE})$ and the Chisquare test $\left(\chi^{2}\right)$ for the confidence interval of $95 \%(P<0.05)$, respectively calculated according to the following equations:

$$
\begin{gathered}
\mathrm{P}=\frac{100}{\mathrm{n}} \sum \frac{|\mathrm{Y}-\hat{\mathrm{Y}}|}{\mathrm{Y}} \\
\mathrm{SE}=\sqrt{\frac{\sum(\mathrm{Y}-\hat{\mathrm{Y}})^{2}}{\mathrm{GLR}}} \\
\chi^{2}=\sum \frac{(\mathrm{Y}-\hat{\mathrm{Y}})^{2}}{\mathrm{GLR}}
\end{gathered}
$$

where:

Y - experimental value;

$\hat{Y} \quad$ - value estimated by the model;

$\mathrm{n}$ - number of experimental observations; and,

GLR - degrees of freedom of the model (number of observations minus the number of parameters of the model).

Brooker et al. (1992) proposed, from the studies of Clausius-Clapeyron, the following equation to quantify the partial vapor pressure contained in porous systems:

$$
\operatorname{In}(\mathrm{Pv})=\left(\frac{\mathrm{L}}{\mathrm{L}^{\prime}}\right) \cdot \operatorname{In}(\mathrm{Pvs})+\mathrm{c}
$$

where:

Pvs - saturation vapor pressure of free water, for certain temperature (T), of equilibrium;

$\mathrm{Pv}$ - vapor pressure of free water, for certain temperature $\mathrm{T}$, of equilibrium;

$\mathrm{L}$ - vaporization latent heat of the water of the product, $\mathrm{kJ} \mathrm{kg}^{-1}$;

L' - vaporization latent heat of free water, at temperature of equilibrium, $\mathrm{kJ} \mathrm{kg}^{-1}$; and,

C - constant of integration.

Based on the obtained curves of equilibrium moisture content, the L/L' relationship in Eq. 14 was determined according to the methodology described by Pereira (1987) for different moisture contents, Xe (d.b.), adjusting the equation for the water vaporization enthalpy presented by Rodrigues Arias (Brooker et al., 1992):

$$
\frac{\mathrm{L}}{\mathrm{L}^{\prime}}-1=\mathrm{a} \exp \left(-\mathrm{b} \cdot \mathrm{Xe}^{\mathrm{m}}\right)
$$

where:

$\mathrm{a}, \mathrm{b}$ and $\mathrm{m}$ - parameters determined through regression.

The vaporization latent heat of free water $\left(\mathrm{kJ} \mathrm{kg}^{-1}\right)\left(\mathrm{L}^{\prime}\right)$ was calculated using the mean temperature $(\mathrm{T})$ in the studied range, in ${ }^{\circ} \mathrm{C}$, through the following equation:

$$
\mathrm{L}=2502.2-2.39 \cdot \mathrm{T}
$$

The saturation vapor pressure of free water, Pvs, was calculated using the Tetens' equation:

$$
\text { PVs }=0.61078 \times 10^{[(7.5 \cdot \mathrm{T}) / 273.3+\mathrm{T}]}
$$

The value of vapor pressure, $\mathrm{Pv}$, was determined according to the following equation:

$$
\mathrm{Pv}=\mathrm{a}_{\mathrm{w}} \cdot \mathrm{Pvs}
$$

where:

$a_{w}$ - water activity, decimal.

In combination, Eqs. 16 and 15 lead to the following expression to estimate the vaporization latent heat of the water of the product (Corrêa et al., 1998):

$$
\mathrm{L}=(2502.2-2.39 \mathrm{~T}) \cdot\left[1+\mathrm{a} \cdot \exp \left(-\mathrm{b} \cdot \mathrm{X}^{\mathrm{m}}\right)\right]
$$

The net isosteric heat of sorption for each equilibrium moisture content was determined using the equation of Clausius-Clayperon (Iglesias \& Chirife, 1976):

$$
\frac{\partial \mathrm{In}\left(\mathrm{a}_{\mathrm{w}}\right)}{\partial \mathrm{T}}=\frac{\Delta \mathrm{h}_{\mathrm{st}}}{\mathrm{RT}_{\mathrm{a}}^{2}}
$$

where:

$\mathrm{Ta}$ - absolute temperature, $\mathrm{K}$;

$\Delta$ hst - differential enthalpy, $\mathrm{kJ} \mathrm{kg}^{-1}$; and,

$\mathrm{R}$ - general gas constant, $8.314 \mathrm{~kJ} \mathrm{kmol}^{-1} \mathrm{~K}^{-1}$, which is $0.4619 \mathrm{~kJ} \mathrm{~kg}^{-1} \mathrm{~K}^{-1}$ for water vapor.

Integrating Eq. 20 and assuming that the net isosteric heat of sorption does not depend on the temperature, the net isosteric heat of sorption for each equilibrium moisture content can be determined according to Eq. 21 (Wang \& Brennan, 1991):

$$
\operatorname{In}\left(\mathrm{a}_{\mathrm{w}}\right)=\left(\frac{\Delta \mathrm{h}_{\mathrm{st}}}{\mathrm{R}}\right) \cdot \frac{1}{\mathrm{~T}_{\mathrm{a}}}+\mathrm{C}
$$

where:

C - coefficient of the model.

The integral isosteric heat of sorption, obtained by adding the value of the vaporization latent heat of pure water to the 
values of net isosteric heat of sorption, according to Eq. 21, necessary for the calculation of $\mathrm{Q}_{\mathrm{st}}$, was determined using Eq. 22:

$$
\mathrm{Q}_{\mathrm{st}}=\Delta \mathrm{h}_{\mathrm{st}}+\mathrm{L}=\mathrm{a} \cdot \exp \left(-\mathrm{b} \cdot \mathrm{Xe} \mathrm{e}^{*}\right)+\mathrm{L}
$$

where:

$\mathrm{Q}_{\mathrm{st}}$ - integral isosteric heat of sorption, $\mathrm{kJ} \mathrm{kg}^{-1}$.

\section{Results AND Discussion}

With the increase in $\mathrm{a}_{\mathrm{w}}$ at the same temperature, there was an increment in the values of equilibrium moisture content for the temperatures of $10,20,30$ and $40^{\circ} \mathrm{C}$ in the studied range of water activity, from 0.20 to 0.84 (Table 1).

The mathematical models used to describe the hygroscopicity of pequi diaspores, for most of its coefficients, showed significance of regression at 0.01 level by $\mathrm{t}$-test (Table 2). In addition, seven models showed high values of coefficient of determination, above 0.95 ; according to Madamba et al. (1996), it indicates satisfactory representation of the studied phenomenon. The coefficient of determination as the only criterion of evaluation for the selection of non-linear models is not a good parameter for the representation of the phenomenon (Mohapatra \& Rao, 2005).

The models Modified BET, Chung Pfost, Copace, GAB, Modified Henderson, Henderson and Peleg showed the lowest values of estimated mean error (SE), compared with the others. The capacity of a model to adequately represent a certain physical process is inversely proportional to the value of the estimated mean error (Draper \& Smith, 1998).

The values of relative mean error $(\mathrm{P})$ were lower than $10 \%$ except for the models BET, Modified Halsey, Sigma Copace, Kuhn and Smith, which, according to Mohapatra \& Rao (2005), indicates adequate representation of the studied phenomenon. Regarding the Chi-square test $\left(\chi^{2}\right)$, the twelve analyzed models are within the confidence interval of $95 \%$; however, based on the magnitude of the values, the model Modified Henderson showed the lowest values in comparison to the others (0.253).

Table 1. Mean values of equilibrium moisture content (Xe $\%$ d.b.) of pequi diaspores, obtained by the process of desorption under different conditions of temperature $\left({ }^{\circ} \mathrm{C}\right)$ and water activity (decimal, \pm 0.03 )

\begin{tabular}{ccccc}
\hline Water activity & \multicolumn{4}{c}{ Temperature $\left({ }^{\circ} \mathbf{C}\right)$} \\
(decimal) & $\mathbf{1 0}$ & $\mathbf{2 0}$ & $\mathbf{3 0}$ & $\mathbf{4 0}$ \\
0.20 & 4.02 & - & - & - \\
0.22 & - & 4.02 & - & - \\
0.25 & - & - & 4.32 & - \\
0.26 & - & - & - & 4.27 \\
0.28 & 6.06 & - & - & - \\
0.31 & - & 6.05 & - & - \\
0.32 & - & - & 6.22 & - \\
0.33 & - & - & - & 6.21 \\
0.41 & 8.33 & - & - & - \\
0.43 & - & - & 7.84 & - \\
0.44 & - & 8.29 & - & 7.7 \\
0.65 & - & - & 10.83 & - \\
0.68 & 13.39 & - & - & 10.72 \\
0.70 & - & 13.41 & - & - \\
0.84 & - & - & 15.14 & 15.2 \\
\hline
\end{tabular}

Table 2. Coefficients of the models adjusted to the hygroscopic equilibrium moisture contents for pequi diaspores with their respective coefficients of determination $\left(R^{2}\right)$, relative $(P)$ and estimated (SE) mean errors and Chisquare $\left(\chi^{2}\right)$

\begin{tabular}{|c|c|c|c|c|c|}
\hline Models & Coefficients & $\mathbf{R}^{2}$ & $\begin{array}{c}P \\
(\%)\end{array}$ & $\begin{array}{c}\text { SE } \\
\text { (decimal) }\end{array}$ & $x^{2}$ \\
\hline Modified BET & $\begin{array}{l}a=12.18877^{*} \\
b=1.86850^{\text {ns }} \\
c=0.50383^{\star *}\end{array}$ & 0.9753 & 6.095 & 1.916 & 0.480 \\
\hline BET & $\begin{array}{l}\mathrm{a}=61.73712^{\star \star} \\
\mathrm{b}=0.34823^{\star \star}\end{array}$ & 0.5530 & 25.754 & 33.591 & 8.147 \\
\hline Chung Pfost & $\begin{array}{l}a=31.89414^{\star \star} \\
b=5.26625^{\star *} \\
c=93.57341^{\star}\end{array}$ & 0.9819 & 6.612 & 1.404 & 0.351 \\
\hline Copace & $\begin{array}{l}\mathrm{a}=1.329342^{\star *} \\
\mathrm{~b}=0.005294^{\star *} \\
\mathrm{c}=1.879629^{\star *}\end{array}$ & 0.9762 & 8.396 & 1.843 & 0.461 \\
\hline Modified Halsey & $\begin{array}{l}a=4.124731^{* *} \\
b=0.010170^{\text {ns }} \\
c=2.020375^{\star *}\end{array}$ & 0.9335 & 12.872 & 5.152 & 1.288 \\
\hline Henderson & $\begin{array}{l}a=0.000067^{* *} \\
b=1.637354^{* *}\end{array}$ & 0.9799 & 6.658 & 1.511 & 0.367 \\
\hline Modified Henderson & $\begin{array}{l}a=0.00019^{* *} \\
b=86.30364^{* *} \\
c=1.62142^{* *}\end{array}$ & 0.9869 & 5.973 & 1.01 & 0.253 \\
\hline Modified Oswin & $\begin{array}{l}a=9.514117^{\star *} \\
b=-0.043465^{\star} \\
c=2.558607^{\star \star}\end{array}$ & 0.9624 & 9.651 & 2.909 & 0.727 \\
\hline Peleg & $\begin{array}{l}a=5748.253^{\text {ns }} \\
b=58.158^{\text {ns }} \\
c=17.485^{\star \star} \\
d=0.932^{* *}\end{array}$ & 0.9771 & 5.690 & 1.835 & 0.474 \\
\hline Kuhn & $\begin{array}{l}\mathrm{a}=1.927009^{* *} \\
\mathrm{~b}=4.841493^{\star *}\end{array}$ & 0.8382 & 18.692 & 12.54 & 3.134 \\
\hline Sigma Copace & $\begin{array}{l}\mathrm{a}=0.533370^{\star \star} \\
\mathrm{b}=0.005234^{\star} \\
\mathrm{c}=1.028713^{\star *}\end{array}$ & 0.9539 & 11.417 & 3.571 & 0.893 \\
\hline Smith & $\begin{array}{l}\mathrm{a}=3.467185^{\star \star} \\
\mathrm{b}=6.846135^{\star *}\end{array}$ & 0.9434 & 10.582 & 4.253 & 1.031 \\
\hline
\end{tabular}

** Significant at 0.01 by t-test; ${ }^{*}$ Significant at 0.05 by t-test; ns Not significant

Günhan et al. (2005) point out that the lower the value of $\chi^{2}$, the better will be the adjustment of the model to the experimental data.

From the tested models, only Modified Henderson showed higher coefficient of determination and lower values of relative mean error and estimated mean error, besides lower magnitude of Chi-square values; thus, it was selected for the prediction of the hygroscopic equilibrium of pequi diaspores. Anselmo et al. (2008), studying isotherms of Bixa orellana, and Bracht et al. (2015), studying seeds of Vitis vinifera, varieties of Cabernet Sauvignon and Ives, observed that Modified Henderson was the best model to represent the experimental data.

For constant water activity (Figure 1), the values of hygroscopic equilibrium moisture contents of pequi diaspores decreased with increase in temperature. The same was observed by Costa et al. (2015b) in seeds of Buchenavia capitata and almonds of Dipteryx alata (Furtado et al., 2014).

Using the values of water activity (Table 3 ), it was possible to calculate the vapor pressure of the equilibrium moisture contents (Eq. 18). With the linearization of the vapor pressure, the latent heat as a function of temperature and the equilibrium moisture content were calculated. The values of the $\mathrm{L} / \mathrm{L}$ relationship, as 


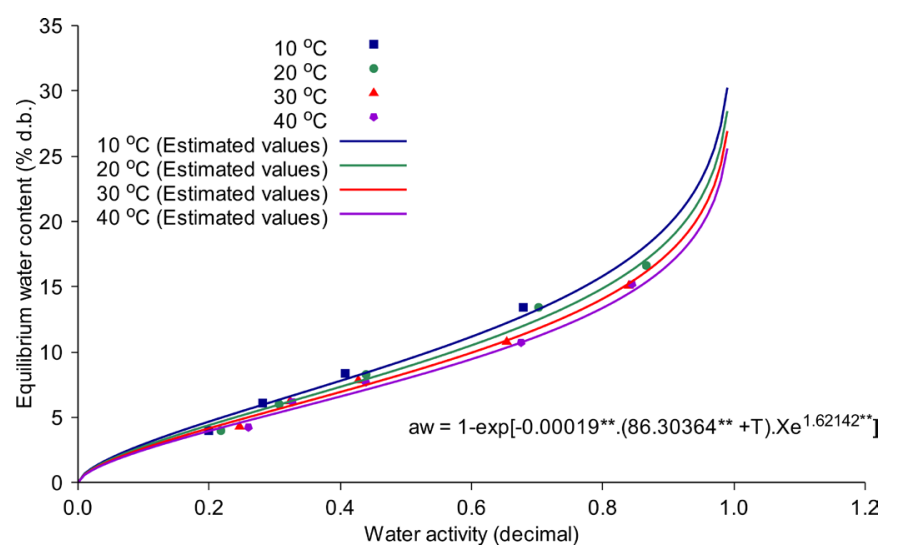

** Significant at 0.01

Figure 1. Experimental values of hygroscopic equilibrium moisture content and desorption isotherms estimated by the Modified Henderson model for pequi diaspores, under different conditions of temperature and water activity

Table 3. Values of water activity (decimal) estimated by the Modified Henderson model for pequi diaspores with moisture contents ranging from 4.02 to 16.63 (\% d.b.) and temperatures of $10,20,30$ and $40{ }^{\circ} \mathrm{C}$ as a function of temperature and equilibrium moisture content $(\mathrm{Xe})$

\begin{tabular}{ccccc}
\hline $\mathbf{X}_{\mathrm{e}}$ & \multicolumn{4}{c}{ Temperature $\left({ }^{\circ} \mathbf{C}\right.$ ) } \\
\cline { 2 - 5 } (\% d.b.) & $\mathbf{1 0}$ & $\mathbf{2 0}$ & $\mathbf{3 0}$ & $\mathbf{4 0}$ \\
4.016 & 0.160 & 0.175 & 0.190 & 0.204 \\
4.021 & 0.160 & 0.175 & 0.190 & 0.205 \\
4.268 & 0.175 & 0.191 & 0.207 & 0.223 \\
4.320 & 0.178 & 0.195 & 0.211 & 0.227 \\
6.047 & 0.287 & 0.312 & 0.336 & 0.359 \\
6.060 & 0.288 & 0.313 & 0.337 & 0.360 \\
6.214 & 0.298 & 0.323 & 0.348 & 0.371 \\
6.220 & 0.298 & 0.324 & 0.348 & 0.372 \\
7.701 & 0.394 & 0.425 & 0.454 & 0.482 \\
7.839 & 0.403 & 0.434 & 0.464 & 0.491 \\
8.291 & 0.431 & 0.464 & 0.494 & 0.523 \\
8.334 & 0.434 & 0.467 & 0.497 & 0.526 \\
10.720 & 0.575 & 0.611 & 0.644 & 0.675 \\
10.830 & 0.581 & 0.618 & 0.651 & 0.681 \\
13.390 & 0.707 & 0.742 & 0.773 & 0.800 \\
13.410 & 0.708 & 0.743 & 0.774 & 0.801 \\
15.140 & 0.777 & 0.809 & 0.836 & 0.860 \\
15.200 & 0.779 & 0.811 & 0.838 & 0.862 \\
16.630 & 0.825 & 0.854 & 0.879 & 0.899 \\
\hline
\end{tabular}

a function of the equilibrium moisture content (\% d.b.), were calculated according to Eq. 15, represented for each situation by the slopes of the lines. The parameters $\mathrm{a}, \mathrm{b}$ and $\mathrm{m}$ of Eq. 16, for the calculation of the ration between vaporization latent heat of pequi diaspores and vaporization latent heat of free water (L/L'), were obtained through non-linear regression and, subsequently, Eq. 19 was used to calculate the values of each vaporization latent heat of the water (Figure 2).

As the equilibrium moisture content increases, there is a decrease in the energy necessary for the evaporation of the water of pequi diaspores. According to Brooker et al. (1992), temperature and especially moisture content are the variables that most influence the vaporization latent heat of the water of the product.

From the linearization of $\mathrm{a}_{\mathrm{w}}$ (Table 3 ), it was possible to determine the values of differential enthalpy of sorption or net isosteric heat of sorption. The values of net isosteric heat

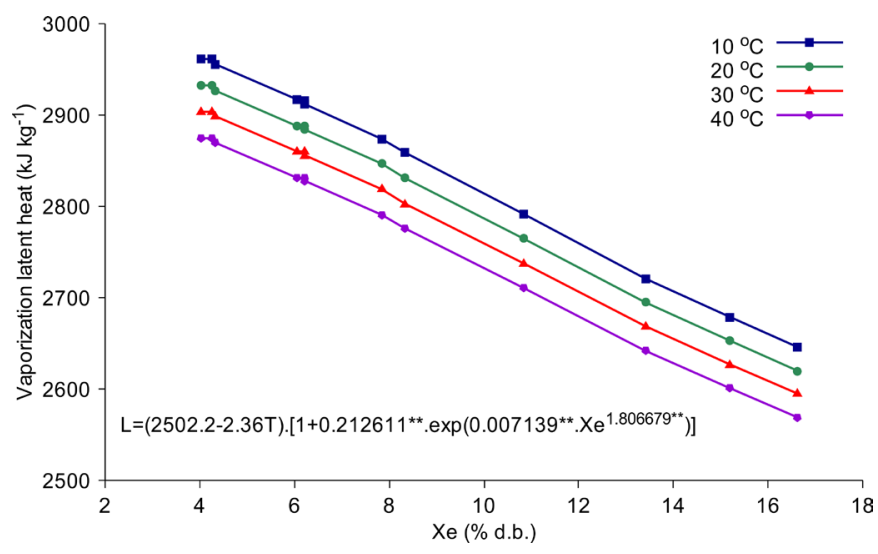

**Significant at 0.01

Figure 2. Vaporization latent heat of water of pequi diaspores at the temperatures of $10,20,30$ and $40{ }^{\circ} \mathrm{C}$

of sorption for pequi diaspores were calculated according to Eq. 22.

According to Figure 3, with the reduction in moisture content, there is an increase in the energy necessary for the removal of water from the product. The values of integral isosteric heat of desorption for pequi diaspores in the moisture content range of 4.02 to 16.63 (\% d.b.) varied from 2,776.49 to $2,558.39 \mathrm{~kJ} \mathrm{~kg}^{-1}$. The same occurred for the seeds of forage turnip (Raphanus sativus L.); the values of integral isosteric heat of desorption, in the moisture content range of 3.33 to 11.30 (\% d.b.), varied from $4,222.70$ to $2,870.34 \mathrm{~kJ} \mathrm{~kg}^{-1}$ (Sousa et al., 2015).

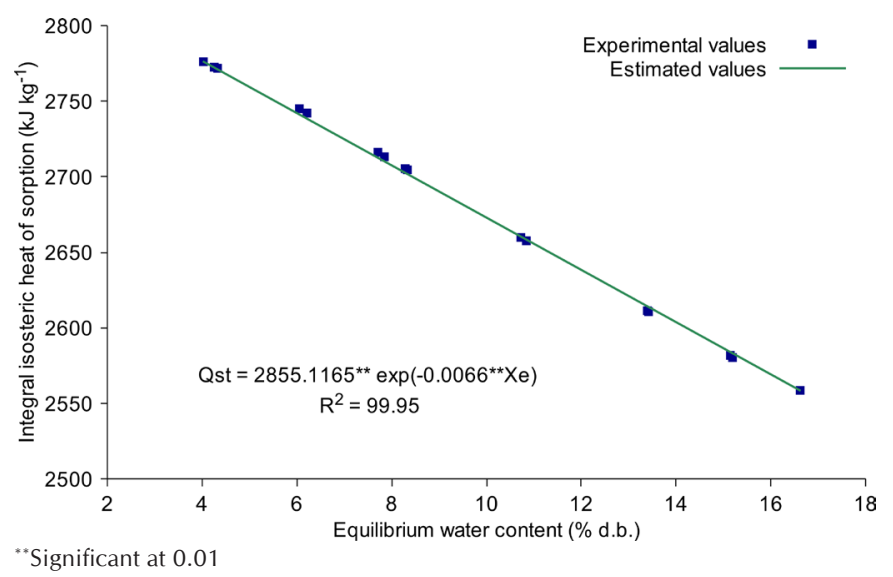

Figure 3. Experimental and estimated values of integral isosteric heat of desorption as a function of equilibrium moisture content

\section{Conclusions}

1. The Modified Henderson model showed the best representation of the hygroscopicity of pequi diaspores compared with the other tested models.

2. Hygroscopic equilibrium moisture content was directly proportional to water activity and decreases with the increase in temperature for the same value of water activity.

3. With the increase in equilibrium moisture content, there was an increase in the energy necessary for the water evaporation and integral isosteric heat of desorption for pequi diaspores in the moisture content range of 4.02 to 16.63 (\% d.b.) varied from $2,776.49$ to $2,558.39 \mathrm{~kJ} \mathrm{~kg}^{-1}$. 


\section{ACKNOWLedgments}

To the Coordination for the Improvement of Higher Education Personnel (CAPES), to the National Council for Scientific and Technological Development (CNPq), the Funding Authority for Studies and Projects (FINEP) and the Instituto Federal Goiano - Campus Rio Verde.

\section{Literature Cited}

Almeida, S. P.; Silva, J. A. Piqui e buriti: Importância alimentar para a população dos Cerrados. Planaltina: Embrapa CPAC, 1994. 38p.

Anselmo, G. C. S; Mata, M. E. R. M. C.; Rodrigues, E. Comportamento higroscópico do extrato seco de urucum (Bixa Orellana L). Ciência e Agrotecnologia, v.32, p.1888-1892, 2008. http://dx.doi. org/10.1590/S1413-70542008000600030

Bracht, C. K.; Menezes, M. L.; Ugri, M. C. B. A.; Pereira, N. C. Determinação das isotermas de equilíbrio das sementes de uva das variedades cabernet sauvignon e bordô. Engevista, v.17, p.44-58, 2015.

Brasil. Ministério da Agricultura e Reforma Agrária. Secretaria Nacional de defesa Agropecuária. Regras para análise de sementes. Brasília: MARA, 2009. 398p.

Brooker, D. B.; Bakker-Arkema, F. W.; Hall, C. W. Drying and storage of grains and oilseeds. New York: van Nostrand Reinhold, 1992. $450 \mathrm{p}$.

Caetano, G. S.; Sousa, K. A.; Resende, O. ; Sales, J. F.; Costa, L.M. Higroscopicidade de sementes de caju-de-árvore-do-cerrado. Pesquisa Agropecuária Tropical, v.42, p.437-445, 2012. http:// dx.doi.org/10.1590/S1983-40632012000400012

Costa, L. M.; Resende, O.; Oliveira, D. E. C. Determinação das isotermas de equilíbrio higroscópico de frutos de crambe pelo método dinâmico. Bioscience Journal, v.31, p.382-391, $2015 \mathrm{a}$. http://dx.doi.org/10.14393/BJ-v31n2a2015-22337

Costa, L. M.; Resende, O.; Oliveira, D. E. C.; Sousa, K. A. Isotermas e calor isósterico de sementes de Buchenavia capitata (Vahl) Eichler. Revista Ciência Agronômica, v.46, p.516-523, 2015b. http://dx.doi. org/10.5935/1806-6690.20150033

Corrêa, P. C.; Christ, D.; Martins, J. H.; Mantovani, B. H. M. Curvas de dessorção e calor latente de vaporização para as sementes de milho pipoca (Zea mays). Revista Brasileira de Engenharia Agrícola e Ambiental, v.2, p.75-79, 1998.

Draper, N. R.; Smith, H. Applied regression analysis. New York: John Wiley \& Sons, 3.ed. 1998. 712p. http://dx.doi. org/10.1002/9781118625590

Furtado, G. F.; Silva, F. S.; Porto, A. G.; Santos, P. Dessorção e calor isotérico de amêndoas de baru. Revista Brasileira de Tecnologia Agroindustrial, v.8, p.1416-1427, 2014. http://dx.doi.org/10.3895/ S1981-36862014000200010

Günhan, T.; Demir, V.; Hancioglu, E.; Hepbasli, A. Mathematical modelling of drying of bay leaves. Energy Conversion and Management, v.46, p.1667-1679, 2005. http://dx.doi.org/10.1016/j. enconman.2004.10.001
Iglesias, H.; Chirife, J. Isosteric heats of water vapour sorption on dehydrated foods. Part II: Hysteresis and heat of sorption comparison with BET theory. Lebensmittel Wissenschaft and Technologie, v.9, p.123-127, 1976.

Madamba, P. S.; Driscoll, R. H.; Buckle, K. A. Thin-layer drying characteristics of garlic slices. Journal of Food Engineering, v.29, p.75-97, 1996. http://dx.doi.org/10.1016/0260-8774(95)00062-3

Mohapatra, D.; Rao, P. S. A thin layer drying model of parboiled wheat. Journal of Food Engineering, v.66, p.513-518, 2005. http://dx.doi. org/10.1016/j.jfoodeng.2004.04.023

Oliveira, G. S.; Costa, J. M. C.; Afonso, M. R. A. Caracterização e comportamento higroscópico do pó da polpa de cajá liofilizada. Revista Brasileira de Engenharia Agrícola e Ambiental, v.18, p.1059-1064, 2014. http://dx.doi.org/10.1590/1807-1929/ agriambi.v18n10p1059-1064

Osório, C.; Franco, M. S.; Castaño, M. P.; Gaonzález-Miret, M. L.; Heredia, F. J.; Morales, A. L. Colour and flavour changes during osmotic dehydration of fruits. Innovative Food Science and Emerging Technologies, v.8, p.353-359, 2007. http://dx.doi. org/10.1016/j.ifset.2007.03.009

Panadés, G.; Castro, D.; Chiralt, A.; Fito, P.; Nuñez, M.; Jimenez, R. Mass transfer mechanisms occurring in osmotic dehydration of guava. Journal of Food Engineering, v.87, p.386-390, 2008. http:// dx.doi.org/10.1016/j.jfoodeng.2007.12.021

Pereira, F. A.; Ferreira, D. A.; Nascimento, J. L. F.; Figueiredo, P. I. Análise da atividade extrativista do pequi (Caryocar coriaceum Wittm) em comunidades da chapada do araripe na região do cariri cearense. Conexões Ciência e Tecnologia, v.8, p.59-66, 2014.

Pereira, J. A. M.; Queiroz, D. M.. Higroscopia, Viçosa: Centreinar, 1987. 28p.

Santos, A. A. C.; Florêncio, A. K. G. D.; Rochas, E. M. F. F.; Costa, J. M. C. Avaliação físico-química e comportamento higroscópico de goiaba em pó obtida por spray-dryer. Revista Ciência Agronômica, v.45, p.508-514, 2014. http://dx.doi.org/10.1590/ S1806-66902014000300010

Silva, D. J. H.; Moura, M. C. C. L.; Casali, V. W. D. Recursos genéticos do banco de germoplasma de hortaliças da UFV: Histórico e expedições de coleta. Horticultura Brasileira, v.19, p.108-114, 2001. http://dx.doi.org/10.1590/S0102-05362001000200002

Sousa, K. A.; Resende, O.; Goneli, A. L. D.; Smaniotto, T. A. S.; Oliveira, D. E. C. Thermodynamic properties of water desorption of forage turnip seeds. Acta Scientiarum Agronomy, v.37, p.11-19, 2015. http://dx.doi.org/10.4025/actasciagron.v37i1.19333

Souza, I.; Salviano, A. A cultura do pequi. Belo Horizonte: EMATER, 2002,10p.

Vera, R.; Naves, R.V.; Nascimento, J. L.; Chaves, L. J.; Leandro, W. M., Souza, E. R. B. Caracterização física de frutos do pequizeiro (Caryocar brasiliense Camb.) no estado de Goiás. Pesquisa Agropecuária Tropical, v.35, p.71-79, 2005.

Wang, N.; Brennan, J. G. Moisture sorption isotherm characteristics of potato at four temperatures. Journal of Food Engineering, v.14, p.269-287, 1991. http://dx.doi.org/10.1016/02608774(91)90018-N 